\title{
Cinecittà w Rzymie - kompleks filmowy, muzealny i technologiczny
}

\begin{abstract}
Streszczenie
Artykuł przedstawia historię i aktualną działalność Cinecittà w Rzymie, jednej z najważniejszych wytwórni filmowych na świecie, zwanej też „Hollywood nad Tybrem”. Autorka zwraca uwagę na fakt, iż dotychczasowe badania skupiają się głównie na kinie włoskim, natomiast Cinecittà pojawia się w nich jako uzupełnienie krytycznej analizy tej kinematografii. Wychodząc od historii powstania wytwórni, która sięga lat trzydziestych ubiegłego wieku, autorka pokazuje w jaki sposób rzymskie miasteczko filmowe zmieniało się na przestrzeni lat i jak wygląda jego sytuacja prawna obecnie. W kolejnym rozdziale opisana jest aktualna działalność Cinecittà, gdzie funkcjonuje profesjonalne studio filmowo-telewizyjne, w którym realizowane są filmy, seriale, reklamy, teledyski i wydarzenia komercyjne, a także muzeum (Cinecittà si mostra) oraz ważna na arenie międzynarodowej instytucja kulturalna (Istituto Luce) o profilu edukacyjnym i promocyjnym. Rozważania uzupełniane są o przykłady filmów wyprodukowanych w rzymskiej wytwórni. W podsumowaniu autorka sugeruje, iż Cinecittà zasługuje na osobne i wnikliwe opracowanie książkowe, którego na polskim gruncie dotychczas nie ma.
\end{abstract}

\section{Słowa kluczowe:}

Rzym, cinecittà, kino włoskie, studio filmowe, miasteczko filmowe

1 Małgorzata Magdalena Lisiecka-Muniak, Dział Rektorski i Organizacji Studiów, Państwowa Wyższa Szkoła Filmowa, Telewizyjna i Teatralna w Łodzi, Polska, e-mail: margaretlisiecka@gmail. com, ORCID ID: https://orcid.org/0000-0003-0841-0904. 


\begin{abstract}
The article presents the history and current activities of Cinecittà in Rome, one of the most important film companies in the world, also known as „Hollywood on the Tiber”. The author draws attention to the fact that the research up to date has focused mainly on Italian cinema, while Cinecittà appears as a supplement to the critical analysis of that cinematography. Starting from the history of the production company, what dates back to 30's of the XX century, the author shows how the Roman film town has changed over the years and what its legal situation is like. The next chapter describes the current activities of Cinecittà, where runs a professional film and television studio, which produces films, series, commercials, music videos, commercial events; a museum (Cinecittà si mostra) and an important and internatrional cultural institution (Istituto Luce) with educational and promotional range. The considerations are complemented with examples of films produced in the company. Summing up, the author suggests that Cinecittà deserves a separate and insightful elaboration, which does not still exist in Polish language.
\end{abstract}

\title{
Keywords:
}

Rome, Cinecittà, Italian cinema, film studio, film town

\section{INSTYTUCJONALNY UNIKAT}

Cinecittà, mieszczące się na obrzeżach Rzymu przy via Tuscolana 1055, to filmowe miasteczko, włoska „fabryka snów”, kolebka klasyki kinematografii włoskiej, obecnie kompleks filmowy, w którym znajdują się: muzeum, instytucje oraz studio filmowo-telewizyjne. Cinecittà w języku włoskim oznacza filmowe miasto i ze względu na wyjątkowe dziedzictwo historyczno-kulturowe w ten sposób często jest określany sam Rzym (warto wspomnieć, że w 2015 roku stolica ta została przyjęta do Sieci Miast Kreatywnych UNESCO jako Miasto Filmu), choć częściej spotkamy się z terminem Hollywood nad Tybrem.

Rzymskie Cinecittà jest europejską rewelacją - filmową, turystyczną i historyczną. Obecnie to świetnie zorganizowane kulturowe przedsięwzięcie, w którym obok siebie funkcjonują zarówno muzeum kinematografii (Cinecittà Si Mostra), nowoczesne studio filmowe (Cinecittà Studios) oraz Instytut LUCE (Istituto Luce). Wszystkie te trzy elementy pełnią bardzo ważną rolę w kreowaniu współczesnej kultury filmowej Włoch, promowaniu dziedzictwa rodzimej kinematografii oraz współtworzeniu nowych dzieł audiowizualnych i stymulowaniu rozwoju branży audiowizualnej (nie tylko za sprawą działalności studia filmowego, ale również 
dzięki funduszom Instytutu LUCE, który współfinansuje rozmaite projekty audiowizualne i kulturowe).

Z prawnego punktu widzenia Cinecittà jest spółką publiczną (wł. Istituto LuceCinecittà S.r.l), podlegającą pod Ministerstwo Kultury i Turystyki (wł. Ministero dei Beni e delle Attività Culturali e del Turismo), współfinansowaną przez Ministerstwo Gospodarki i Finansów (wł. Ministero dell’Economia e delle Finanze). Pozornie jej aktualna struktura organizacyjna może wydawać się skomplikowana, szczególnie dla osób kojarzących Cinecittà głównie jako filmowe miasteczko, w którym powstały dzieła przede wszystkim Federica Felliniego, ale też Luchina Viscontiego czy Roberta Rosselliniego. Często zapomina się o obszarach, w których instytucja obecnie prężnie działa: ochrona dóbr dziedzictwa kulturowego, promocja włoskiej kinematografii i edukacja filmowa, a także produkcja filmowo-telewizyjna.

Przypadek o tyle ciekawy, że dotychczas w polskim piśmiennictwie naukowym Cinecittà pojawiała się jedynie jako element anegdotyczny uzupełniający rozważania historyczne lub krytyczne o kinie włoskim, jako wspomnienie o miejscu realizacji zdjęć danego filmu. Brakuje natomiast tekstów poświęconych samej instytucji, jak często się to dzieje w przypadku badań nad działalnością muzeów czy szkół filmowych. Wydaje się, że wynika to z faktu, iż współczesne kino włoskie zajmuje raczej skromną pozycję w polskiej myśli filmoznawczej, a badaczy bardziej interesują procesy historyczne, tendencje stylistyczne czy sylwetki poszczególnych twórców kina niż kultura filmowa i jej wątki poboczne².

Czym w takim razie była Cinecittà, a czym jest obecnie? Czy w radykalny sposób zmieniła się jej funkcja? Jaką rolę pełni we współczesnej kulturze filmowej? Moim celem jest zaprezentowanie jej profilu działalności z wyraźnym przypomnieniem, iż jest ona jedną z najważniejszych instytucji kulturowych w kraju. Rzymskie miasteczko filmowe liczy ponad osiemdziesiąt lat, dlatego, aby zrozumieć ten kulturowy fenomen, warto przyjrzeć się korzeniom całego przedsięwzięcia i procesowi, jakiemu zostało ono poddane, ażeby współcześnie stać się jedną z bardziej znaczących wytwórni filmowych na świecie i jedynym takim miejscem w Europie.

2 Zresztą również w Polsce takie „odłamy” badań kulturowych, jak kultura filmowa czy turystyka filmowa, zajmują drugorzędne miejsce. Por. Kultura filmowa współczesnej Łodzi, red. E. Ciszewska, K. Klejsa, Wydawnictwo Biblioteki PWSFTviT, Łódź 2015. 


\section{OD PROPAGANDY DO KINA AUTORSKIEGO}

Paradoksalnie słynna Cinecittà powstała jako narzędzie faszystowskiej propagandy. W literaturze włoskiej często pojawia się określenie „stabilimenti cinematografici”, które przetłumaczyć można jako wytwórnia filmowa, ale również - bardziej dosłownie - jako zakłady kinematograficzne, co językowo bardziej odzwierciedla ideologiczny charakter całego przedsięwzięcia. To właśnie 28 kwietnia 1937 roku jej działalność, wówczas największej i najbardziej nowoczesnej wytwórni filmowej w Europie, zaingurował sam Benito Mussolini ${ }^{3}$. Miasteczko ulokowano w nowoczesnej dzielnicy EUR-u, w bliskiej odległości od niedawno utworzonej (w 1935 r.) włoskiej szkoły filmowej (Centro Sperimentale di Cinematografia), zaś sama budowa zajęła piętnaście miesięcy.

Cinecittà ma kilku ojców założycieli, o których należy tutaj wspomnieć: Benito Mussolini, jeden z inicjatorów i zwolennik pomysłu budowy centrum filmowego, dzięki któremu byłby w pełni realizowany faszystowski program wychowawczy; Vittorio Mussolini, wielki entuzjasta kina, zaangażowany w tworzenie kultury filmowej (był m.in. redaktorem magazynu „Cinema” wydawanego w latach 1936-1943), później również producent i scenarzysta filmowy; Luigi Freddi, dziennikarz zafascynowany kalifornijskim studiem filmowym, którego duce mianował dyrektorem do spraw kinematografii w Cinecittà; Carlo Roncoroni, właściciel wytwórni Cines, jednej z największych wytwórni filmowych we Włoszech, której budynek uległ zniszczeniu w pożarze w 1935 roku, co również było jedną z motywacji do rozpoczęcia budowy miasteczka przy via Tuscolana; wreszcie Gino Peressutti, architekt, którego zatrudniono do zaprojektowania nowej wytwórni, a który zaś sam inspiracje czerpał, odwiedzając znamienite europejskie studia filmowe w Berlinie, Londynie czy Paryżu (Gravino, 2012, s. 34-35).

Sam projekt okazał się niemałym wyzwaniem architektonicznym, bowiem teren Cinecittà do dzisiaj obejmuje aż 587738 metrów kwadratowych, w tym kilka placów, aleje drzew (obsadzonych ponad 400 sosnami) i, oczywiście, 21 hal zdjęciowych ${ }^{4}$. Na terenie kompleksu pozostaje też niezabudowana przestrzeń przeznaczona na realizację zdjęć w plenerze. Zresztą nie tylko sama budowa centrum filmowego była odzwierciedleniem Hollywood. Na Półwyspie Apenińskim,

${ }^{3}$ Warto nadmienić, że nie była to jedyna wytwórnia produkująca filmy we Włoszech w latach trzydziestych XX wieku. Równolegle działały inne, w których powstawały m.in. filmy artystyczne czy eksperymentalne. Należały do nich Scalera Film, Lux czy Minerva Film.

${ }^{4}$ Co ciekawe, hale zdjęciowe ponumerowane są od 1 do 22, bez numeru 17. 
na wzór amerykańskiego systemu gwiazd, promowano nowe produkcje poprzez wizerunki występujących w nich aktorek. Takie osobowości jak Doris Duranti, Clara Calamai, Isa Miranda, Alida Valli w szybkim czasie stały się diwami włoskiego kina lat trzydziestych XX wieku, ikonami kultury filmowej tego okresu.

Jeszcze w roku 1937 uruchomiono produkcję kilku filmów, a jednym z nich był Scypion afrykański (wł. Scipione l’africano, reż. Carmine Gallone, 1937), obraz opiewający włoskie działania wojenne w Etiopii i plany kolonialne. Monumentalne sceny zainscenizowane w przestrzeni Cinecittà, kadry przesycone egzotyką (zarówno pod względem krajobrazów, jak i obecności zwierząt), aprobata samego duce (który kilkukrotnie odwiedził plan filmowy) zaowocowały ogromnym sukcesem kasowym filmu. Był to również efekt wzmożonej kampanii reklamowej, propagowanej przez władze państwowe. Film współcześnie należy do wzorcowych przykładów nacjonalistycznego kina lat trzydziestych oraz obrazuje produkcyjny potencjał wytwórni z ówczesnych czasów.

Innym obrazem spod szyldu Cinecittà, nakręconym w duchu kina faszystowskiego, który dodatkowo odniósł sukces na Festiwalu Filmowym w Wenecji w 1938 roku, był Pilot Luciano Serra (wł. Luciano Serra Pilota, reż. Goffredo Alessandrini, 1938). Film przypadł do gustu Vittoriowi Mussoliniemu, a to za sprawą nowoczesnych rozwiązań formalnych, które wykorzystał reżyser: zmiany punktów widzenia, zdjęcia z lotu ptaka, skontrastowanie planów, kładąc tym samym nacisk na efektywność scen batalistycznych i futurystyczną estetykę (Miczka, 2009, s. 75-76).

W latach 1937-1943 w rzymskiej wytwórni wyprodukowano 279 filmów (Conti, 2012, s. 11). Początkowa działalność i funkcjonalność Cinecittà była w przejrzysty sposób określona przez dominujący system polityczny: seryjna produkcja kina gatunkowego (z zamiłowaniem do kina historycznego) o wyraźnym, ideologicznym sznycie, promującym faszystowski styl życia (Miczka, 2009, s. 97). Ówczesne ideowo-estetyczne starcia pomiędzy artystami chcącymi wyłamać się spod kurateli nacjonalistycznych ministrów a wiernymi dygnitarzom państwowym twórcami są ciekawym tłem historycznym produkowanych wówczas filmów. Artyści z intelektualną zajadliwością wskazywali na tendencyjność, uproszczoną dramaturgię i dydaktyzm kina promowanego przez ministerstwa.

Działania zbrojne prowadzone w czasie drugiej wojny światowej wstrzymały większość produkcji filmowych, a budynki wytwórni uległy zniszczeniu. Do roku 1946, a nawet 1947, mieścił się tam obóz wysiedleńczy utworzony przez aliantów, ale Niemcy zdążyli już wcześniej zagrabić większość jej mienia (Conti, 2012, s. 11-14). W pamięć zapada zdjęcie z 1946 roku ze zdigitalizowanego archiwum braci Alinari (wł. Gestione Archivi Alinari), które przedstawia główne wejście 
na teren Cinecittà - obozu wysiedleńczego z napisem „PRZEJSCIOWY OBÓZ REPATRIACYJNY" .

Jednak mit prawdziwego „Hollywood nad Tybrem” narodził się w późnych latach pięćdziesiątych i na początku lat sześćdziesiątych XX wieku. Tuż po wojnie w kinie uformowały się tendencje neorealistyczne, lecz większość z tych arcydzieł powstała w naturalnych plenerach, co było zgodne z konwencją kina prawdy. Natomiast potrzeba było kilku lat, by odbudować zdewastowaną Cinecittà. W tym czasie produkowano filmy historyczne, kino gatunkowe (w tym spaghetti westerny, komedie i tzw. peplum), a nawet powstawały koprodukcje włosko-amerykańskie. Jedną z nich był kasowy Ksiq̨żę lisów z udziałem Orsona Wellesa (ang. Prince of Foxes, reż. Henry King, 1949). Zresztą sam Welles wielokrotnie bywał w Rzymie. Produkcje te otworzyły tzw. epokę filmów kolossal ${ }^{6}$ : monumentalnych pod względem wizualnym i rozbudowanych fabularnie produkcji historycznych, takich jak: Quo Vadis (reż. Mervyn LeRoy, 1951), Ben Hur (reż. William Wyler, 1959) czy Kleopatra (ang. Cleopatra, reż. J.L. Mankiewicz, 1963).

Paradoksalnie na Półwysep Apeniński amerykańskich producentów przyciągały obowiązujące tu warunki ekonomiczno-produkcyjne, które m.in. dzięki tzw. prawom Andreottiego ${ }^{7}$ liberalizowały ich artystyczne pomysły i usprawniały produkcyjne dążenia.

W końcu „złote czasy” nastały wraz z narodzinami demiurgicznego talentu filmowego: Federica Felliniego. Wiele swoich filmów nakręcił on w wytwórni, niejednokrotnie okupując kilka hal zdjęciowych naraz. Natomiast jego ulubioną była hala z numerem $5^{8}$, na której dziś wisi tablica upamiętniająca dwudziestolecie jego śmierci (obchodzone w 2013 roku) . Słodkie życie (wł. La dolce vita, 1960),

${ }^{5}$ Pisownia oryginalna. Zdjęcie: Państwowy Instytut Luce, Sfollati davanti all'ingresso di Cinecittà, (1946, 6 grudnia), Alinari.it. https://www.alinari.it/it/esplora-immagini?isPostBack=1\& page $=1 \&$ step $=64 \&$ position=113\&viewtype=grid\&id_dossier=\&showPageInfo=1\&getCodiciSearc $\mathrm{h}=0$ \&query=cinecitta\&paginate_pageNum $=1 \&$ view $=\&$ datafotoda $=\&$ datafotoa $=\&$ querywe $=\&$ fond $\mathrm{o}=$ \&artista $=\&$ fotografo $=$ \&personaggio $=$ \&luogo $=$ \&periodostile $=$ \&evento $=$ \&inventario $=$ \&elencoco dici=\&tecnica=\&tipooggetto=\&orderby=default\&pageNumber=2 [dostęp: 6.01.2020].

6 Termin pochodzący z języka francuskiego i niemieckiego, który dosłownie znaczy „kolosalny”.

7 Ustawy nr 448 z 25 lipca 1949 roku i nr 958 z 29 listopada 1949. Ustawy te szczegółowo regulowały zasady i warunki finansowania produkcji i dystrybucji filmowej, ale nie ograniczały ingerencji zagranicznego kapitału i udziału niewłoskich produkcji w rynku audiowizualnym. Dla Giuglia Andreottiego był to sposób inwestycji w przemysł i kino państwowe.

8 W języku włoskim „hala zdjęciowa” tłumaczy się jako „teatro da posa”, co pod względem znaczeniowym i metaforycznym zbliża inscenizację na hali zdjęciowej do inscenizacji na deskach teatru.

9 Na tablicy wyryto słowa Felliniego (tłumaczenie z języka włoskiego - M.L.-M.): „Kiedy pytają mnie o to, w jakim mieście chciałbym mieszkać, czy w Londynie, Paryżu, Rzymie... A ja 
Casanova (1976), Miasto kobiet (wł. La città delle donne, 1980) - to tylko niektóre tytuły mistrza wyprodukowane w murach rzymskiej wytwórni, ale to właśnie sukces artystyczny Słodkiego życia zwrócił uwagę światowej publiczności na filmowy krajobraz Rzymu, ową dwuznaczność „cinecittà”, która odnosi się i do wytwórni, i do miasta. Jednym z symboli Cinecittà, które dzisiaj „wita” zwiedzających przekraczających bramę wejściową, jest rzeźba Venusia, zaprojektowana przez Giantita Burchiellara do scenografii Casanovy.

Dynamiczna produkcja kina włoskiego o szerokim wachlarzu nurtów, gatunków i poetyk trwa aż do późnych lat osiemdziesiątych, kiedy to rozpoczął się głęboki kryzys ekonomiczny. Do tego czasu w Cinecittà nieustannie produkowane były filmy włoskie i zagraniczne. Na planach zdjęciowych gościły wielkie osobowości rodzimej kinematografii: Anna Magnani, Giulietta Masina, Sophia Loren, Vittorio De Sica, Marcello Mastroianni, Roberto Begnini, Claudia Cardinale, ale również gwiazdy amerykańskie: Jane Fonda, Liz Taylor, Kirk Douglas. Do tego setki pracowników ekipy produkcyjnej i tysiące statystów.

Lata dziewięćdziesiąte to okres wielu przemian prawno-organizacyjnych i dzielenia udziałów wytwórni, która przekształcana była w różnego rodzaju spółki. W 1993 roku $^{10}$, z udziałami Ministerstwa Gospodarki i Finansów, powstaje Cinecittà Holding S.p.A (włoska spółka akcyjna), jednak juz w roku 1997 studia filmowe (jako Cinecittà Studios S.p.A.) trafiają w ręce prywatnej grupy Italian Entertainment Group, której prezesem zostaje niezwiązany z branżą filmową Luigi Abete $^{11}$. W 2009 roku nastąpiło połączenie spółki Cinecittà Holding i Instytutu LUCE, czego efektem był twór Cinecittà Luce S.p.A. W 2017 roku, po dwudziestu latach prywatyzacji, spółka odkupiła studia filmowe i kompleks ten do dnia dzisiejszego funkcjonuje w formie prawnej jako Istituto Luce-Cinecittà S.r.l. - włoska spółka z ograniczoną odpowiedzialnością (Silipo, 2011; Rigitano 2015) ${ }^{12}$.

szczerze odpowiadam, że wybrałbym Cinecittà. Hala numer 5 to miejsce idealne. Zaangażowany, podekscytowany, zafascynowany, tak czuję się, kiedy stoję przed pustą halą: to przestrzeń do wypełnienia, świat do wykreowania”.

10 Na podstawie Dekretu z mocą ustawy nr 118, z dnia 23 kwietnia 1993 roku, przekształconego później w Ustawę nr 202, z dnia 23 czerwca 1993 roku.

11 Luigi Abete był natomiast prezesem banku BNL (Banca Nazionale del Lavoro), który wielokrotnie udzielał finansowania na produkcję filmową we Włoszech.

12 Odtworzenie tych faktów było pewnym wyzwaniem, ponieważ brakuje literatury i danych na ten temat. Źródłem przedstawionych informacji są: dane ze strony internetowej https://cinecitta. com, akty prawne umieszczone we włoskim Dzienniku Ustaw (wł. Gazzetta Ufficiale) oraz włoskie artykuły prasowe. 


\section{FABRYKA FILMOWO-TELEWIZYJNYCH SNÓW}

Również dzisiaj Cinecittà oferuje zaawansowane usługi produkcyjno-realizacyjne. Kompleks, dzięki przemyślanej infrastrukturze, jest przygotowany do prowadzenia kilku projektów w jednym czasie. By przywołać konkretne liczby, warto zaznaczyć, że wytwórnia mieści: wspomniane 21 hal zdjęciowych, 11 elektrowni, 21 garderób, 280 pokoi biurowych. W 2018 roku spółka zatrudniała 247 pracowników na umowach stałych (na czas nieokreślony) i 16 na umowach czasowych ${ }^{13}$. Nie są natomiast podane dane dotyczące pracowników dorywczych czy stażystów. Jednakże sądząc po liczbie i rozmachu zrealizowanych produkcji, można mówić o setkach osób codziennie przebywających na terenie wytwórni: asystentach reżyserów, operatorach obrazu, scenografach, rekwizytorach, stolarzach, krawcowych, statystach itp.

W Cinecittà Studios powstają filmy fabularne, programy telewizyjne, seriale, reklamy, teledyski, a sale wynajmowane są nawet na wydarzenia komercyjne. Zakres oferowanych usług obejmuje: budowę scenografii i dekorację wnętrz, postprodukcję obrazu w profesjonalnym studiu przystosowanym do montażu i efektów specjalnych, postprodukcję dźwięku w studiu nagrań, digitalizację materiałów z taśmy filmowej, pełną obsługę produkcyjną (Cinecittà Hub), począwszy od poszukiwania lokacji, zapewnienia transportu czy cateringu, aż po dobór i ustawienie oświetlenia na planie. To własnie dzięki zaawansowanej technologii Cinecittà utrzymuje czołowe miejsce wśród studiów filmowych na świecie: możliwość produkcji w formacie $4 \mathrm{~K}$, a także w formatach wymaganych przez telewizję czy platformy VOD (Netflix czy Amazon), projektowanie i realizacja efektów specjalnych, produkcja z użyciem technologii CGI i zaawansowana korekcja kolorów.

W „Hollywood nad Tybrem” powstały m.in. Gangi Nowego Jorku (ang. Gangs of New York, reż. Martin Scorsese, 2002); film, do którego scenografia (odtworzenie XIX-wiecznego Nowego Jorku) została zrealizowana w Cinecittà dzięki współpracy reżysera z duetem wybitnych scenografów: Dantem Ferrettim oraz Fransceską Lo Schiavo. Innym tytułem z wizualnymi ambicjami i produkcyjnym rozmachem był Nine - Dziewięć (ang. Nine, reż. Rob Marshall, 2009), na halach zdjęciowych zbudowano teatralną scenografię i nakręcono choreograficzne popisy aktorów; to kolejny musical w dorobku twórcy Chicago, który choć poniósł arty-

13 Podane dane są udostępnione w Biuletynie Informacji Publicznej Istituto Luce Cinecittà (wł. amministrazione trasparente). 
styczną i finansową porażkę, sprowadził do Rzymu takie gwiazdy, jak Penélope Cruz, Nicole Kidman, Kate Hudson, Marion Cotillard, co relatywnie wpłynęło na promocję Rzymu.

Jednak na szczególną uwagę zasługują dwa filmy o podobnej, eklezjastycznej tematyce: włoski Habemus Papam - mamy papieża (wł. Habemus Papam, reż. Nanni Moretti, 2011) oraz koprodukcja argentyńsko-włosko-amerykańska Dwóch papieży (ang. The Two Popes, reż. Fernando Meirelles, 2019). W obu utworach audiowizualnych ma miejsce scena elekcji papieskich, które tradycjnie odbywają się w Kaplicy Sykstyńskiej. Jednakże w rzeczywistości niemożliwa jest realizacja zdjęć filmowych na terenie Watykanu, dlatego obie te sceny zostały zrealizowane właśnie w studio Cinecittà (Reinstein, 2019; Montini, 2011). Co więcej, w Dwóch papieżach uczestniczymy w scenie intymnego dialogu między Benedyktem XVI a Franciszkiem, która rozgrywa się w całkowicie pustej przestrzeni, tuż pod sklepieniem ze znamienitymi freskami Michała Anioła. Uzyskany efekt wizualno-emocjonalny był możliwy tylko dzięki przemyślanej inscenizacji i dokładnemu (rzeczywistemu) odtworzeniu kaplicy w hali zdjęciowej. Na potrzeby filmu Habemus Papam - mamy papieża została również zrekonstruowana Loża Błogosławieństw, z której ogłaszany jest wybór nowego papieża.

Produkcyjne możliwości, zaplecze technologiczne, wszechstronne wyposażenie, zaawansowana technika pracy na planie zdjęciowym sprawiają, że Cinecittà jest najbardziej profejsonalnym studiem filmowym w Europie. O jej światowej konkurencyjności świadczy liczba zrealizowanych zagranicznych produkcji, do których należą: Pasja (ang. The Passion of the Christ, reż. Mel Gibson, 2004) czy Podwodne życie ze Stevem Zissou (ang. The Life Aquatic wih Steve Zissou, reż. Wes Anderson, 2004).

Jak już wspomniano, w Cinecittà produkowane są także inne formy telewizyjne. Często dekoracje do różnych projektów powstają tuż obok siebie, a ekipy realizacyjne pracują równocześnie, z pełnym poszanowaniem wzajemnej pracy. Obok Kaplicy Sykstyńskiej odtworzonej do filmu Morettiego stoi dom włoskiego Wielkiego Brata, gdzie życie młodych uczestników programu rejestrują telekamery. W taki sposób Cinecittà przedstawia Francesco Piccolo w eseju zawartym w książce Cinecittà. Una magia senza fine, pisząc o „dwutorowości” wytwórni, swoistym i ciągłym dialogu kina i telewizji balansującego na granicy akceptacji i rywalizacji (Piccolo, 2012, s. 79); starciu, które najpełniej wybrzmiało w Ginger i Fred Felliniego (wł. Ginger e Fred, reż. Federico Fellini, 1986).

Rynek audiowizualny bywa bezwzględny, płynność finansowa jest warunkiem gwarantującym przetrwanie, a tego typu przestrzenie nie mogą stać puste; w przeciwnym razie mogłaby się zakończyć działalność wytwórni, co spotkało 
między innymi małopolskie Alwernia Studios. Dlatego w studiu o takim dziedzictwie historyczno-kulturowym muszą powstawać również produkcje komercyjne zapewniające zysk.

\section{MUZEALNY SZLAK PO HISTORII KINA WŁOSKIEGO}

W Cinecittà na szeroką skalę prowadzona jest działalność muzealna, dydaktyczna i turystyczna. Na początku lat dziewięćdziesiątych, pod rządami dyrektora Stefana Gasbarra, jeszcze pod szyldem Cinecittà Holding, zostały otwarte bramy miasteczka dla turystów (Miczka, 1993, s. 480). Dziś ta część kompleksu funkcjonuje pod nazwą Cinecittà si mostra i jest jednym z najciekawszych i najlepiej zorganizowanych muzeów filmowych w Europie, które, eksponując bogate zbiory piśmiennicze, scenograficzne i audiowizualne, opowiada o początkach wytwórni, historii kina włoskiego oraz o procesie produkcji filmu w ogóle.

Wystawy stałe podzielone są chronologicznie oraz tematycznie i są to:

1) „Kręcić film w Cinecittà”14 (wł. Girando a Cinecittà) - to historia o filmach powstałych w wytwórni, od początku powstania miasteczka w latach trzydziestych, przez „złote lata” pięćdziesiąte i sześćdziesiąte, okres tzw. boomu ekonomicznego we Włoszech, aż po rok 1990;

2) „Backstage” - ścieżka dydaktyczna po Cinecittà (wł. Backstage - un percorso didattico per Cinecittà) - to interaktywna trasa poprzez sale, z których każda poświęcona jest innej profesji filmowej: reżyserii, scenariopisarstwu, udźwiękowieniu, projekcji kostiumów, pracy w technologii green screen;

3) „Łódź podwodna” (wł. Il sottomarino) - to fragment scenografii - okrętu podwodnego S-33 - do amerykańskiego filmu U-571 (reż. Jonathan Mostow, 2000); sceny podwodne zostały nakręcone w hali zdjęciowej Cinecittà;

4) „Felliniana - Feretti wyśnił Felliniego” (wł. Felliniana - Ferretti sogna Fellini) - szlak zaprojektowany przez wspomniany wyżej wybitny duet scenograficzny (Dante Ferretti i Franscesca Lo Schiavo), który opowiada o nieograniczonej wyobraźni filmowej Federica Felliniego.

Co więcej, zwiedzający mogą równiez zobaczyć stałe dekoracje plenerowe, na które wejście obowiązuje wyłącznie z przewodnikiem. W plenerze znajdują się trzy wystawy stałe i są to:

14 Wszystkie tłumaczenia nazw wystaw stałych z języka włoskiego - M. L-M. 
1) „Starożytny Rzym” (wł. Roma Antica) - scenografia zbudowana na potrzeby serialu telewizyjnego Rzym (ang. Rome, prod. HBO, 2005-2007), która była również wykorzystywana do innych projektów, np. w 2011 roku odbył się tu występ zespołu Coldplay;

2) „Świątynia Jerozolimska” (wł. Il Tempio di Gerusalemme) - scenografia wykreowana do filmu Młody Mesjasz (ang. The Young Messiah, Cyrus Nowrasteh, 2016);

3) „Florencja 1400” (wł. Firenze 1400) - dekoracje zaprojektowane dla miniserialu telewizyjnego Franciszek (wł. Francesco, Michele Soavi, 2002), które wykorzystano też do innych projektów.

Nie można zapomnieć o instytucjonalnej funkcji Cinecittà, za którą odpowiada Instytut LUCE. To tak naprawdę najstarszy twór miasteczka filmowego, bowiem utworzony w 1924 roku przez samego Benita Mussoliniego. Współcześnie Luce to jedna z najważniejszych instytucji w dziedzinie kinematografii w kraju, licząca się również za granicą (przedstawiciele instytutu są corocznie obecni na najważniejszych festiwalach filmowych w Cannes, Wenecji, Locarno, Szanghaju czy Nowym Jorku).

Misją statutową Instytutu Luce jest promocja współczesnego kina włoskiego na arenie międzynarodowej, stymulacja rozwoju kultury filmowej, a także digitalizacja, gromadzenie, restaurowanie i udostępnianie włoskiego dziedzictwa filmowego. Instytut współpracuje również z Ambasadą Włoch w Polsce. Wspólnie z Instytutami Włoskimi w Warszawie i Krakowie co roku organizowany jest przegląd nowego kina Półwyspu Apenińskiego (Cinema Italia Oggi) w kinach w największych polskich miastach: Warszawie, Krakowie, Łodzi czy Wrocławiu.

Poprzez różne formy dofinansowania Luce jest też koproducentem projektów filmowych, a także dystrybuuje kino autorskie i debiutujących reżyserów. Wśród tych tytułów znajdują się m.in.: Mafia to już nie to, co kiedyś (wł. La mafia non é più quella di una volta, reż. Franco Maresco, 2019), Fuocoammare. Ogień na morzu (wł. Fuocoammare, reż. Gianfranco Rosi, 2016), Piękna i utracona (wł. Bella e perduta, reż. Pietro Marcello, 2015), Zaprzysiężona dziewica (wł. Vergine Giurata, reż. Laura Bispuri, 2015).

Instytut dysonuje bogatym archiwum filmowym, a kolekcja wideoteki liczy 3000 zbiorów filmowych i fotograficznych. W 2013 roku archiwum to otrzymało odznaczenie UNESCO Pamięć Świata (ang. Memory of the World International Register). Dodatkowo jest wydawcą magazynu filmowego „81르”, a także odpowiada za redakcję informacji na strony internetowe: Cinecittà News (www.news. cinecitta.com), Italy for Movies (www.italyformovies.it) i Film Italia (www. filmitalia.org). 


\section{NA PIERWSZY PLAN}

Cinecittà to symbol włoskiej kinematografii, kopalnia wiedzy dla badaczy europejskiej kinematografii, atrakcja turystyczna dla osób odwiedzających Rzym. Wreszcie, to prężnie działające studio filmowe, które dzięki zapleczu technologicznemu przyciąga producentów z całego świata, chcących zrealizować w niej swoje projekty, od kina autorskiego po komercyjne przedsięwzięcia.

Nie sposób wymienić wszystkich filmów wyprodukowanych w „Hollywood nad Tybrem” - od końca od lat trzydziestych XX wieku do obecnych czasów powstało ich ponad trzy tysiące. Warto natomiast, by Cinecittà stała się pierwszoplanową bohaterką poświęconego jej opracowania, w którym to filmy będą tłem historii rozgrywających się w jej wnętrzach, a nie odwrotnie, jak miało to miejsce w dotychczasowych publikacjach. Źródłem cennych informacji mogą stać się publikacje w języku włoskim, których już kilka powstało. Dodatkowo warto wskazać, że zakulisowe opowieści o procesie powstawania filmów mają dwa źródła: pierwszym są wywiady z ich twórcami, a drugim realizacje audiowizualne typu making of, raczej niechętnie udostępniane szerokiej publiczności.

Podsumowując, Cinecittà to osiemdziesiąt lat historii o ludziach: nie tylko reżyserach i aktorach, ale również operatorach obrazu, scenografach, producentach, garderobianych, urzędnikach, przedstawicielach wszystkich profesji filmowych, które - jak zazwyczaj się zdarza - pozostają w cieniu znanych nazwisk, choć niektóre z nich znalazły już swoje miejsce w salach Cinecittà si mostra. Warto pamiętać, że współcześnie Cinecittà jest ważnym i wielowymiarowym ośrodkiem kulturowym, który może stanowić punkt odniesienia wielu badań naukowych (filmoznawców, kulturoznawców, italianistów, historyków) czy pracy artystów (filmowych, estradowych). Wreszcie, dzięki długoletniej tradycji i wyraźnie sprecyzowanej metodzie upowszechniania włoskiej kultury filmowej, może stać się wzorem do naśladowania czy inspiracją dla polskich instytucji o podobnym profilu.

\section{Bibliografia}

Ciszewska, E., Klejsa K. (red.) (2015). Kultura filmowa współczesnej Łodzi. Łódź: Wydawnictwo Biblioteki PWSFTviT.

Conti, M. (2012). Silenzio, si gira la storia. Cronaca e finzione negli studios dalla nascita a oggi. W: D. Hamaui (red.), Cinecittà. Una magia senza fine (wyd. 1, s. 10-23). Rzym: National Geographic Italia.

Di Biagi, F. (2006). Rzym w filmie włoskim. Tłum. E. Maciszewska. W: G.M. Grabowska (red.), Warszawa i Rzym. Kino-topografia dwóch miast (wyd. 1, s. 94-102). Warszawa: Filmoteka Narodowa. 
Gravino, M. (2012). Una California in periferia. Gli studios che dovevano sfidare Hollywood. W: D. Hamaui (red.), Cinecittà. Una magia senza fine (wyd. 1, s. 34-39). Rzym: National Geographic Italia.

Hamaui, D. (red.) (2012). Cinecittà. Una magia senza fine. Roma: National Geographic Italia.

Miczka, T. (2009). Kino włoskie. Gdańsk: Słowo/Obraz Terytoria.

Miczka, T. (1993). W Cinecittà i okolicach. Historia kina włoskiego od połowy lat pięćdziesiatych do końca lat osiemdziesiątych $X X$ wieku. Kraków: Oficyna Literacka.

Montini, F. (2011). Il Vaticano di Nanni Moretti nella Roma austera di „Habemus Papam”. Pobrane z: https://roma.repubblica.it/cronaca/2011/04/15/news/habemus_papam_il_ fil_di_moretti_a_roma-14960191/.

Piccolo, F. (2012). Cinema e tv, binario doppio, W: D. Hamaui (red.), Cinecittà. Una magia senza fine (wyd. 1, s. 74-83). Rzym: National Geographic Italia.

Reinstein, M. (2019). How the Sistine Chapel Was Re-created For „The Two Popes”. Pobrane z: https://www.architecturaldigest.com/story/the-two-popes-movie-set-design -interview.

Rigitano, E. (2015). L'amara vita di Cinecittà Studios, tra rilancio e scetticismo. Pobrane z: https://www.linkiesta.it/2015/09/lamara-vita-di-cinecitta-studios-tra-rilancio-e -scetticismo/.

Silipo, R. (2011). Che cos'è Cinecittà. Pobrane z: https://www.lastampa.it/cultura /2011/03/10/news/che-cos-e-cinecitta-1.36974299\#: :text=Quando\%20\%C3\%A8\%20 nata\%20Cinecitt\%C3\%A0\%3F,stranieri\%20stimolando\%20la\%20produzione\%20 nazionale. 